\title{
Pengaruh Medan Listrik sebagai Stimulan Pertumbuhan Bawang Putih Lokal Timor
}

\author{
Gede Arya Wiguna ${ }^{(1, a) *}$, Welsiliana ${ }^{(1, b)}$, Florian Mayesti Prima R. Makin ${ }^{(1, c)}$ \\ dan Ite Morina Yostianti Tnunay ${ }^{(1, d)}$
}

\author{
${ }^{1}$ Program Studi Biologi, Fakultas Pertanian, Universitas Timor, NTT, Indonesia, 85613 \\ Email: ${ }^{\left({ }^{*}\right)}$ gede.arya@unimor.ac.id, ${ }^{(b)}$ welsiliana@unimor.ac.id, ${ }^{(c)}$ florian@unimor.ac.id, \\ (d)ite_tnunay@unimor.ac.id.
}

Diterima (28 Juni 2021), Direvisi (25 Juli 2021)

\begin{abstract}
The decline in Timorese local garlic yields will have an impact on farmers' income and the existence of the garlic. One of the decline factors is production. The purpose of this study is the implementation of an electric field as a stimulant for garlic growth. The electric field used is an AC electric field with an output frequency of $1.0 \mathrm{kHz}$. The variation of the electric field used is 1.28, 1.55, 1.80, 2.12, and $2.48 \mathrm{kV} / \mathrm{m}$. The results showed that exposure to an electric field in garlic resulted in a better germination rate, average germination time, and shoot and root growth rate compared to the control. The treatment of exposure to an electric field of $1.55 \mathrm{kV} / \mathrm{m}$ resulted the most optimum in the germination rate, average germination time and growth rate of shoots and roots with the respective values (11.4 \pm 0.6$) \% /$ etmal, (1.4 \pm $0,1)$ day, $(2.83 \pm 0.09) \mathrm{mm} /$ day, and $(2.04 \pm 0.09) \mathrm{mm} /$ day. Increasing germination, shortening the average germination time and growth rate are expected to increase local Timor garlic production.
\end{abstract}

Keyword: Timor local garlic, Electric field, Growth

\begin{abstract}
Abstrak. Penurunan hasil panen bawang putih lokal Timor akan berdampak pada penghasilan petani dan keberadaan bawang putih tersebut. Salah satu faktor penurunan adalah produksi. Tujuan pada penelitian ini yaitu implementasi medan listrik sebagai stimulan pertumbuhan bawang putih. Medan listrik yang digunakan adalah medan listik AC dengan frekuensi keluaran sebesar 1,0 kHz. Variasi besar medan listrik yang digunakan yaitu $1,28,1,55,1,80,2,12$ dan $2,48 \mathrm{kV} / \mathrm{m}$. Hasil menunjukkan bahwa paparan medan listrik pada bawang putih menghasilkan laju berkecambah, waktu rerata berkecambah, serta kecepatan tumbuh tunas dan akar lebih baik terhadap kontrol. Perlakuan paparan medan listrik $1,55 \mathrm{kV} / \mathrm{m}$ menghasilkan laju perkecambahan, rerata waktu berkecambah dan kecepatan tumbuh tunas dan akar paling optimum dengan nilai masing-masing $(11,4 \pm 0,6) \% / \mathrm{etmal},(1,4 \pm 0,1)$ hari, $(2,83 \pm 0,09) \mathrm{mm} / \mathrm{hari}$, dan $(2,04 \pm 0,09)$ $\mathrm{mm} /$ hari. Peningkatan daya berkecambah, mempersingkat rerata waktu berkecambah dan kecepatan tumbuh diharapkan dapat meningkatkan produksi bawang putih Timor lokal.
\end{abstract}

Kata kunci: Bawang putih lokal Timor, Medan listrik, Pertumbuhan

\section{PENDAHULUAN}

Bawang putih (Allium sativum L.) merupakan tanaman holtikultura yang memiliki banyak manfaat. Selain digunakan untuk bumbu penyedap [1] bawang putih juga dapat digunakan sebagai anti mikrobia [2] Kandungan dalam bawang putih yang bernama alisin dapat dimanfaatkan dalam bidang bidang farmakologi seperti menurunkan tekanan darah [3], mencegah pembekuan darah (antitrombotik) [4], pencegahan aterosklerosis, pengurangan kolesterol serum dan trigliserida, penghambatan agregasi platelet dan peningkatan fibrinolitik [5]. 
Di Indonesia, terdapat 13 varietas bawang putih lokal. Varietas tersebut adalah Saigon, Lumbu Kuning, Krisik, Sanggah, Lumbu Hijau, Tiongkok, Tawangmangu, Teki, Ciwidey, NTT, Thailand, China, dan Pingpong (Thailand) [6]. Bawang putih NTT merupakan bawang putih varietas lokal Timor yang ditanam di Desa Fatuneno, Kecamatan Miomafo Barat, Kabupaten Timor Tengah Utara (TTU), NTT. Budidaya bawang putih lokal di desa ini dilakukan secara turun-temurun dan merupakan salah satu komoditi unggulan di Kabupaten TTU[7].

Hasil panen bawang putih lokal Timor dari tahun 2015-2018 mengalami penurunan yang cukup drastis. Hasil panen tahun 2015 sebanyak 17 Ton dan tahun 2018 sisa 0,5 ton [8]. Penurunan hasil panen disebabkan karena kurang efisiennya penggunaan lahan, proses pembibitan, lambatnya pertumbuhan, tenaga kerja, pupuk, obat-obatan dan faktor-faktor sosial [9]. Jika kondisi semacam ini terus berlanjut maka dapat berdampak pada penghasilan petani dan keberadaan bawang putih lokal Timor tersebut.

Salah satu upaya untuk memperbaiki keadaan tersebut yaitu dengan cara penerapan paparan medan listrik (Pulsed Electric Field). Paparan medan listrik pada bawang putih berpotensi menyebabkan perubahan permeabilitas membran sel bawang putih [10], yang dapat memicu berbagai reaksi biokimia dan enzimatik pada sel[11]. Reaksi tersebut dapat memicu dan menjadi stimulan percepatan masa pecah dormansi dan pertumbuhan tanaman bawang putih. Melalui percepatan masa dormansi dan pertumbuhan diharapkan diperolehnya hasil produksi yang lebih baik.

\section{METODE PENELITIAN}

Penelitian ini terdiri dari empat tahapan yaitu desain medan listrik, pemilihan bibit bawang putih, paparan medan listrik, dan pengamatan pertumbuhan (Gambar 1). Pembangkit medan listrik yang digunakan merupakan hasil rancangan Tim Peneliti yang ditunjukkan pada Gambar 2. Alat ini memiliki toleransi tegangan $\pm 10 \%$. Komponen alat terdiri dari catu daya (power supply), pengatur tegangan (voltage selector), pembangkit sinyal listrik (signal generator), pengatur frekuensi (frequency selector), dan plat aluminium sebagai elektroda.

Sampel bawang putih lokal Timor yang digunakan adalah bawang putih bersiung tunggal dengan massa antara 1,05 - 1,13 gram. Bawang putih dikelompokkan kedalam 6 perlakuan dengan 5 ulangan.

Bawang putih selanjutnya ditempatkan pada wadah di antara dua plat elektroda. Dua plat elektroda berjarak $1 \mathrm{~cm}$ disesuaikan dengan diameter bibit bawang putih mendekati $1 \mathrm{~cm}$ sehingga paparan medan listrik terfokus pada bibit bawang putih. Variasi besar medan listrik yang dipaparkan yaitu 1,28, 1,55, 1,80, 2,12 dan $2,48 \mathrm{kV} / \mathrm{m}$.

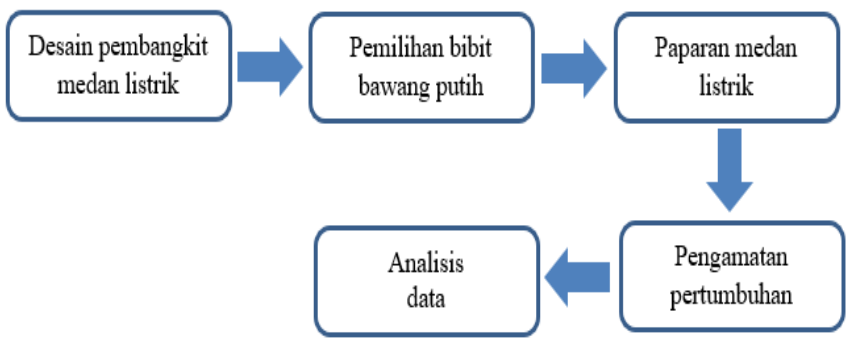

Gambar 1. Tahapan penelitian

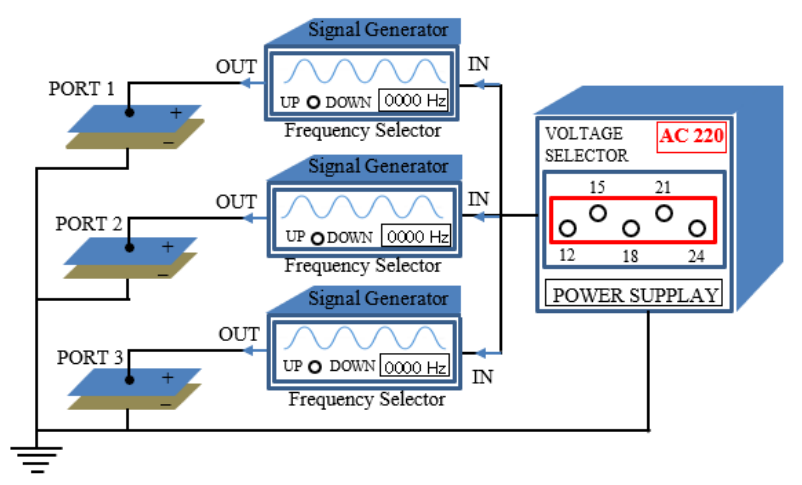

Gambar 2. Desain pembangkit medan listrik 


\section{Daya Kecambah}

Daya berkecambah adalah keserempakan benih bawang putih untuk berkecambah. Pengamatan daya kecambah dilakukan dari hari pertama sampai pada hari ketujuh. Daya kecambah dihitung menggunakan Persamaan 1.

$D K=\sum x_{i}{ }_{N} \times 100 \%$

dengan $D K$ adalah daya kecambah, $\sum x_{i}$ adalah jumlah benih yang berkecambah pada hari ke- $i$ dan $N$ adalah jumlah benih yang akan dikecambahakan

\section{Laju Kecambah}

Pengamatan laju berkecambah bawang putih dilakukan dari hari pertama sampai hari ketujuh. laju berkecambah dihitung menggunakan Persamaan 2.

$v_{k}=\Sigma^{B_{i}} / T_{i}$

dengan $v_{k}$ adalah laju kecambah, $B_{i}$ adalah

banyak kecambah normal pada hari ke-i dan $T_{i}$ adalah waktu berkecambah hari ke-i. Waktu rerata berkecambah dihitung menggunakan persamaan 3.

$t_{k}=\sum B_{i} \times T_{i} / \sum N$

dengan $t_{k}$ adalah waktu rerata berkecambah, $B_{i}$ adalah banyak kecambah normal pada hari ke-i, $T_{i}$ adalah waktu berkecambah hari ke-i dan $N$ jumlah total benih berkecambah.

\section{Laju Pertumbuhan}

Laju pertumbuhan benih bawang putih pada penelitian ini diamati berdasarkan perubahan panjang tunas dan perubahan panjang akar. Pengamatan laju pertumbuhan dilakukan dengan mengukur perubahan panjang tunas terhadap waktu dan perubahan panjang akar terhadap waktu bawang putih dari hari pertama sampai hari ketujuh. Laju pertumbuhan tunas dan akar dapat dihitung menggunakan Persamaan 4. $v_{p}=\Delta S / \Delta t$

dengan $v_{p}$ adalah laju pertumbuhan tunas atau akar, $\Delta S$ adalah perubahan Panjang tunas atau akar dan $\Delta t$ adalah perubahan waktu.

\section{Analisis Data}

Data yang diperoleh dari pengamatan pertumbuhan selanjutnya dihitung rerata dan standar deviasinya berdasarkan ulangan. Hasil yang diperoleh disajikan dalam bentuk tabel dan grafik. Analisis data juga dilakukan menggunakan Statistical Package for the Social Sciences (SPSS). Apabila hasil sidik ragam menunjukkan pengaruh nyata dari perlakuan, maka dilakukan uji lanjut Duncan Mean Range Test (DMRT).

\section{HASIL DAN PEMBAHASAN}

\section{Daya Berkecambah, Laju Berkecambah dan Waktu Rerata Berkecambah}

Hasil pengamatan daya perkecambahan bawang putih dalam 7 hari ditampilkan pada Gambar 3. Data yang ditampilkan berupa rata-rata dan standar deviasi dari ke-5 ulangan. Hasil menunjukan adanya peningkatan daya berkecambah. Perlakuan paparan medan listrik $1,2 \mathrm{kV} / \mathrm{m}$ dan $1,5 \mathrm{kV} / \mathrm{m}$ memiliki daya berkecambah mencapai $100 \%$ pada hari ke 3. Perlakuan paparan medan listrik $1,8 \mathrm{kV} / \mathrm{m}$ dan kontrol mencapai daya berkecambah $100 \%$ pada hari ke 5 . Sedangkan perlakuan paparan medan listrik 2,1 $\mathrm{kV} / \mathrm{m}$ dan $2,4 \mathrm{kV} / \mathrm{m}$ baru mencapai $96 \%$ pada hari ke 7 . Hal ini menunjukan bahwa paparan medan listrik dengan tegangan yang bervariasi mempengaruhi daya berkecambah bawang putih lokal Timor.

Berdasarkan data daya berkecambah bawang putih, maka dapat dihitung laju berkecambahnya menggunakan persamaan 1 dan waktu rerata berkecambah menggunakan persamaan 2. Hasil laju perkecambahan dan waktu rerata berkecambah ditampilkan pada Tabel 1. 


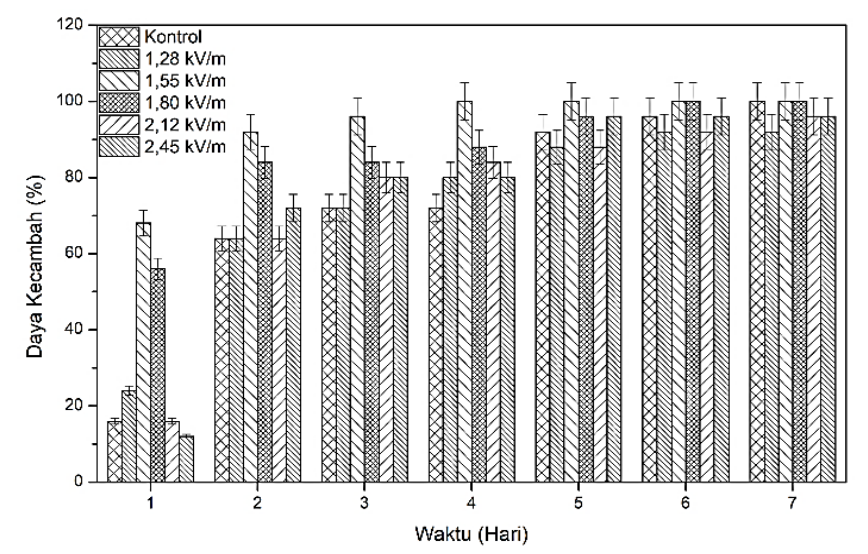

Gambar 3. Diagram daya berkecambah terhadap waktu perkecambahan benih bawang putih selama 7 hari.

Tabel 1. Laju berkecambah dan waktu rerata berkecambah antara perlakuan dan kontol pada benih bawang putih

\begin{tabular}{ccc}
\hline Perlakuan & $\begin{array}{c}\text { Laju } \\
\text { Kecambah } \\
\text { (\%/etmal) }\end{array}$ & $\begin{array}{c}\text { Waktu Rerata } \\
\text { Berkecambah } \\
\text { (Hari) }\end{array}$ \\
\hline Kontrol & $(6,2 \pm 0,3) \mathrm{a}$ & $(3,2 \pm 0,2) \mathrm{a}$ \\
$1,28 \mathrm{kV} / \mathrm{m}$ & $(7,8 \pm 0,4) \mathrm{a}$ & $(1,9 \pm 0,1) \mathrm{bc}$ \\
$1,55 \mathrm{kV} / \mathrm{m}$ & $(11,4 \pm 0,6) \mathrm{b}$ & $(1,4 \pm 0,1) \mathrm{c}$ \\
$1,80 \mathrm{kV} / \mathrm{m}$ & $(10,4 \pm 0,5) \mathrm{b}$ & $(1,7 \pm 0,1) \mathrm{bc}$ \\
$2,12 \mathrm{kV} / \mathrm{m}$ & $(7,6 \pm 0,4) \mathrm{a}$ & $(2,4 \pm 0,1) \mathrm{b}$ \\
$2,45 \mathrm{kV} / \mathrm{m}$ & $(7,5 \pm 0,4) \mathrm{a}$ & $(2,2 \pm 0,1) \mathrm{b}$ \\
\hline
\end{tabular}

Keterangan: huruf $\mathrm{a}, \mathrm{b}, \mathrm{c}$ menunjukkan pembeda nilai yang nyata dari setiap perlakuan pada uji DMRT (Duncan's Multiple Range Test) dengan taraf $\alpha=0.05$.

Pada Tabel 1. Data dan standar deviasi laju kecambah dan waktu rerata berkecambah dihitung berdasarkan rata-rata dari 5 ulangan. Secara keseluruhan, perlakuan dengan paparan medan listrik memiliki laju berkecambah yang lebih tinggi dibandingkan dengan kontrol. Laju berkecambah kontrol paling rendah yaitu $6,2 \pm 0,3 \% /$ etmal. Perlakuan paparan sebesar $1,28 \mathrm{kV} / \mathrm{m}$ ( dengan laju berkecambah $7,8 \pm 0,4 \quad \%$ /etmal), $2,12 \mathrm{kV} / \mathrm{m}$ (dengan laju berkecambah 7,6 \pm $0,4 \% /$ etmal) dan $2,45 \mathrm{kV} / \mathrm{m}$ (dengan laju berkecambah 7,5 $\pm 0,4 \%$ /etmal), memiliki laju berkecambah yang tidak berbeda tidak secara signifikan pada uji DMRT (Duncan's Multiple Range Test) dengan taraf $\alpha=0.05$. Perlakuan paparan medan listrik sebesar $1,55 \mathrm{kV} / \mathrm{m}$ (dengan laju berkecambah 11,4 $\pm 0,6 \%$ /etmal) dan 1,80 $\mathrm{kV} / \mathrm{m}$ (dengan laju kecambah 10,4 $\pm 0,5$ \%/etmal) memiliki laju berkecambah yang berbeda secara signifikan.

Waktu rerata berkecambah bawang putih secara keseluruhan pun menunjukan bahwa kontrol memiliki waktu rerata berkecambah lebih lama dibandingkan dengan yang diberi perlakuan paparan medan listrik (Tabel 1). Kontrol memiliki waktu rerata berkecambah $(3,2 \pm 0,2)$ hari. Perlakuan paparan medan listrik sebesar $1,28 \mathrm{kV} / \mathrm{m}$ dan $1,80 \mathrm{kV} / \mathrm{m}$ memiliki waktu rerata berkecambah masing-masing $(1,9 \pm$ $0,1)$ hari dan $(1,7 \pm 0,1)$ hari. Kedua perlakuan tersebut menunjukan waktu rerata berkecambah tidak berbeda secara signifikan. Perlakuan paparan medan listrik sebesar 1,55 kV/m memiliki nilai optimum waktu rerata berkecambah yaitu $(1,4 \pm 0,1)$ hari. Paparan medan listrik mempengaruhi daya, laju dan waktu rerata berkecambah bawang putih lokal Timor. Daya kecambah umbi bawang putih akan memperlihatkan cepat atau lambatnya pematahan dormansi. Masa dormansi yang dimulai sejak masa pemanenan berpengaruh pada turunnya proses fisiologis umbi bawang. Seperti pada bawang bombay berakhirnya masa dormansi ditandai oleh penurunan zat penghambat tumbuh dan meningkatnya giberelin[12]. Selain karena paparan medan listrik, daya berkecambah juga dipengaruhi oleh adanya hormon tumbuhan yang sudah tersimpan di dalam umbi sejak masa dorman. Hormon ini membantu dalam perkecambahan umbi, terutama dalam pematahan dormansi bawang [13][14]. Paparan medan listrik mengakibatkan adanya transpor elektron sehingga terjadi perubahan posisi ion positif dan ion negatif di dalam membran umbi [10][15]. Transpor elektron merupakan proses pengangkutan elekron melewati membran baik itu pada membran plasma maupun pada organel sel yang memiliki membran seperti kloroplas dan mitokondria. Proses pengangkutan 
elektron melibatkan protein pembawa misalnya ubiquinone. Transport elektron sangat penting terutama pada saat pembentukan energi sel[16]. Hal tersebut berdampak pada permebilitas membran sel dan memacu proses pertumbuhan tanaman dengan memecah atau mempercepat pertumbuhan sel tanaman. Dengan demikian menstimulasi umbi bawang putih untuk mulai berkecambah. Selain itu, medan listrik dapat pula mempengaruhi ion transport pada saat proses perkecambahan terutama saat proses penyerapan air. Berubahnya permeabilitas membran dapat mempengaruhi metabolisme serta pola pergerakan ion dalam sel tanaman[17].

\section{Pertumbuhan Tunas dan Akar}

Hasil pertumbuhan tunas dan akar rata-rata bawang putih yang diamati selama 7 hari dapat dilihat pada Gambar 3. Dari gambar diperoleh grafik pertumbuhan tunas dan akar bawang putih lokal Timor. Pertumbuhan tunas paling cepat diperoleh dari perlakuan paparan medan listrik 1,55 $\mathrm{kV}$ dikuti $1,28 \mathrm{kV} ; 2,12 \mathrm{kV} ; 2,45 \mathrm{kV} ; 1,80$ $\mathrm{kV}$; dan kontrol adalah yang paling rendah pertumbuhannya (Gambar 3a). Pengamatan pertumbuhan akar bawang putih lokal Timor menunjukan nilai paling tinggi adalah yang diberi paparan medan listrik $1,55 \mathrm{kV}$ selanjutnya $1,80 \mathrm{kV} ; 1,28$ $\mathrm{kV} ; 2,45 \mathrm{kV} ; 2,12 \mathrm{kV}$; dan paling rendah adalah kontrol (Gambar 3b).

Berdasarkan data pertumbuhan tunas dan akar bawang putih diperoleh rerata kecepatan pertumbuhannya dengan menggunakan persamaan 4. Data rerata kecepatan pertumbuhan tunas dan akar ditampilkan pada Tabel 2. Secara keseluruhan rerata laju pertumbuhan tunas dan akar dengan perlakuan paparan medan listrik lebih tinggi dibandingkan dengan kontrol. Rerata laju pertumbuhan tunas dengan paparan medan listrik $1,55 \mathrm{kV}$ menunjukan rerata laju pertumbuhan paling tinggi yaitu $1,80 \pm 0,05 \mathrm{~mm} / \mathrm{hari}$ sedangkan kontrol paling rendah laju pertumbuhannya yaitu $1,08 \pm 0,05 \mathrm{~mm} /$ hari.

Tabel 2. Rerata laju pertumbuhan tunas dan akar bawang putih perlakuan kontrol dan perlakuan paparan medan listrik

Kecepatan pertumbuhan

\begin{tabular}{ccc}
\multirow{2}{*}{ Perlakuan } & \multicolumn{2}{c}{ (mm/hari) } \\
\cline { 2 - 3 } & Tunas & Akar \\
\hline Kontrol & $(1,08 \pm 0,05) \mathrm{a}$ & $(1,10 \pm 0,06) \mathrm{a}$ \\
$1,28 \mathrm{kV} / \mathrm{m}$ & $(1,80 \pm 0,05) \mathrm{b}$ & $(1,61 \pm 0,08) \mathrm{b}$ \\
$1,55 \mathrm{kV} / \mathrm{m}$ & $(2,83 \pm 0,09) \mathrm{c}$ & $(2,04 \pm 0,09) \mathrm{c}$ \\
$1,80 \mathrm{kV} / \mathrm{m}$ & $(1,29 \pm 0,06) \mathrm{ab}$ & $(1,70 \pm 0,08) \mathrm{bc}$ \\
$2,12 \mathrm{kV} / \mathrm{m}$ & $(1,73 \pm 0,09) \mathrm{b}$ & $(1,29 \pm 0,06) \mathrm{ab}$ \\
$2,45 \mathrm{kV} / \mathrm{m}$ & $(1,51 \pm 0,08) \mathrm{ab}$ & $(1,51 \pm 0,08) \mathrm{b}$ \\
\hline
\end{tabular}

Keterangan: huruf a, b, c menunjukkan pembeda nilai yang nyata dari setiap perlakuan pada uji DMRT (Duncan's Multiple Range Test) dengan taraf $\alpha=0.05$.

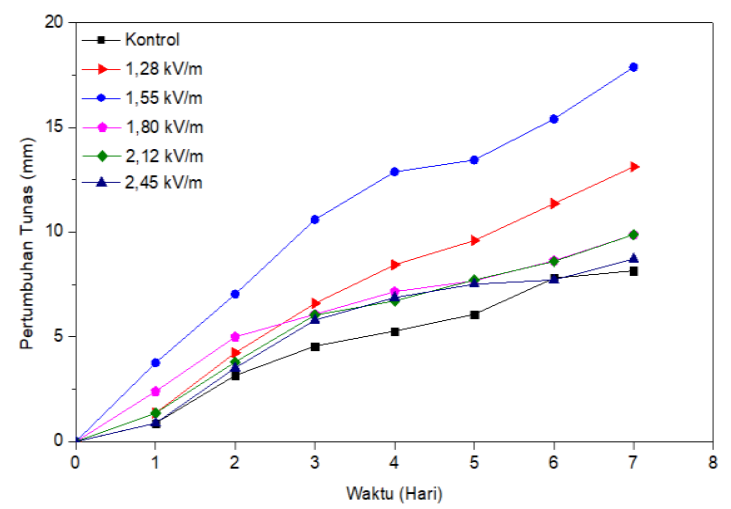

(a)

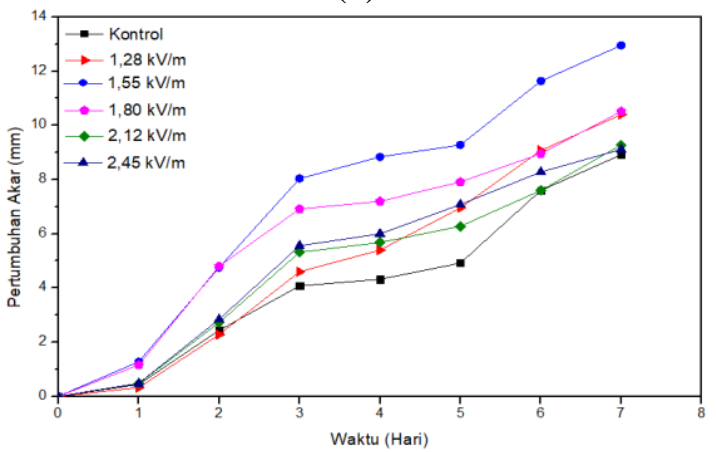

(b)

Gambar 3. Grafik rerata pertumbuhan Bawang Putih Kontrol dan Perlakuan; (a) Tunas, (b) Akar 
Rerata laju pertumbuhan akar pun menunjukan hasil yang tidak jauh berbeda dengan tunas. Paparan medan listrik 1,55 $\mathrm{kV}$ tetap menunjukan rerata laju pertumbuhan akar paling besar yaitu 1,55 $\mathrm{kV}(2,04 \pm 0,09) \mathrm{mm} / \mathrm{hari}$, sedangkan kontrol $(1,10 \pm 0,06) \mathrm{mm} /$ hari.

Berdasarkan uji DMRT, rerata laju pertumbuhan tunas dan akar bawang putih lokal Timor menunjukan perbedaan yang signifikan antara pemberian paparan 1,55 $\mathrm{kV}$ dengan kontrol. Hal tersebut menggambarkan bahwa paparan medan listrik mempengaruhi rerata laju pertumbuhan tunas dan akar bawang putih lokal Timor.

Pertumbuhan tunas dan akar pada benih bawang putih dipengaruhi oleh metabolisme yang terjadi di dalam sel bawang putih tersebut. Metabolisme adalah keseluruhan reaksi kimia yang terjadi pada makhluk hidup. Metabolisme pada tumbuhan terbagi atas dua kelompok yaitu anabolisme dan katabolisme. Anabolisme adalah pembentukan molekul-molekul kompleks dari molekul-molekul sederhana dan membutuhkan energi misalnya fotosintesis, sedangkan katabolisme merupakan penguraian molekul yang kompleks menjadi molekul yang sederhana dan membentuk energi contohnya respirasi[16]. Paparan medan listrik dapat berpengaruh pada aktivitas keseluruhan tanaman yang berkaitan dengan metabolisme elektron dan ion [18].

\section{KESIMPULAN}

Paparan medan listrik pada bawang putih lokal Timor dapat membantu mempercepat laju berkecambah, waktu rerata berkecambah, serta kecepatan pertumbuhan tunas dan akar. Perlakuan paparan medan listrik sebesar $1,55 \mathrm{kV} / \mathrm{m}$ memiliki nilai optimum pada laju perkecambahan $(11,4 \pm 0,6)$ \%/etmal, waktu rerata berkecambah $(1,4 \pm 0,1)$ hari, cepat pertumbuhan tunas $(2,83 \pm 0,09)$ $\mathrm{mm} /$ hari dan cepat pertumbuhan akar $(2,04$ $\pm 0,09) \mathrm{mm} /$ hari.

\section{UCAPAN TERIMAKASIH}

Terima kasih dihaturkan kepada Lembaga Penelitian dan Pengabdian Masyarakat Universitas Timor yang telah mendanai penelitian ini melalui skema Penelitian Dosen Pemula dengan Nomor Kontrak 21/UN60/LPPM/PP/2021. Ucapan terima kasih juga disampaikan kepada Fakultas Pertanian Universitas Timor yang memberikan sarana dan prasarana pada penelitian ini.

\section{DAFTAR PUSTAKA}

[1] Y. Sholihin, E. Suminar, W. H. Rizky, and G. G. Pitaloka, "Pertumbuhan eksplan meristem bawang putih (Allium sativum L.) kultivar tawangmangu pada berbagai komposisi kinetin dan GA3 In Vitro," Kultivasi, vol. 15, no. 3, 2016 doi: 10.24198/kultivasi.v15i3.11769.

[2] T. I. Purwantiningsih, A. Rusae, and Z. Freitas, "Uji in vitro antibakteri ekstrak bawang putih sebagai bahan alami untuk menghambat bakteri Staphylococcus aureus dan Escherichia coli," J. UNS, vol. 17, no. 1, 2019.

[3] K. Ried, O. R. Frank, and N. P. Stocks, "Aged garlic extract reduces blood pressure in hypertensives: A dose-response trial," Eur. J. Clin. Nutr., vol. 67, no. 1, 2013, doi: 10.1038/ejen.2012.178.

[4] P. Mikaili, S. Maadirad, M. Moloudizargari, S. Aghajanshakeri, and S. Sarahroodi, "Therapeutic uses and pharmacological properties of garlic, shallot, and their biologically active compounds," Iranian Journal of Basic Medical Sciences, vol. 16, no. $\quad 10 . \quad 2013, \quad$ doi: 10.22038/ijbms.2013.1865. 
[5] J. Y. Y. Chan, A. C. Y. Yuen, R. Y. K. Chan, and S. W. Chan, "A review of the cardiovascular benefits and antioxidant properties of allicin," Phytotherapy Research, vol. 27, no. 5. 2013, doi: 10.1002/ptr.4796.

[6] M. N. Moulia et al., "Antimikroba Ekstrak Bawang Putih Antimikroba Ekstrak Bawang Putih Antimicrobial of Garlic Extract," 2018.

[7] M. Falo, S. J. Kune, A. N. Hutapea, and O. B. Kapitan, "Faktor-Faktor yang Mempengaruhi Produksi dan Strategi Pengembangan Usahatani Bawang Putih di Kecamatan Miomaffo Barat, Kabupaten Timor Tengah Utara," AGRIMOR, vol. 1, no. $\quad 04, \quad 2016, \quad$ doi: 10.32938/ag.v1i04.113.

[8] Badan Pusat Statistik Timor Tengah Utara, Statistik Pertanian Kabupaten Timor Tengah Utara 2018. Kefamenanu: Badan Pusat Statistik, 2019.

[9] S. J. Kune and A. N. Hutapea, "Efisiensi Penggunaan Input Usahatani Bawang Putih Lokal Ebandi Miomaffo Barat Kabupaten Timor Tengah Utara," J. Manaj. AGRIBISNIS (Journal Agribus. Manag., vol. 6, no. 1, 2018, doi: 10.24843/jma.2018.v06.i01.p05.

[10] A. Angersbach, V. Heinz, and D. Knorr, "Effects of pulsed electric fields on cell membranes in real food systems," Innov. Food Sci. Emerg. Technol., vol. 1, no. 2, 2000, doi: 10.1016/S1466-8564(00)00010-2.

[11] T. Tantamacharik, S. Y. Leong, M. J. Leus, G. T. Eyres, D. J. Burritt, and I. Oey, "Structural changes induced by pulsed electric fields increase the concentration of volatiles released in red onion (Allium cepa L. Var. Red pearl) bulbs," Foods, vol. 8, no. 9, 2019, doi: 10.3390/foods8090368.

[12] P. Miedema, "Bulb dormancy in onion. I.The effects of temperature and cultivar on sprouting and rooting," J. Hortic. Sci., vol. 69, no. 1 , 1994 , doi: 10.1080/14620316.1994.11515245.

[13] C. Y. Mantoko and T. D. Kurnia, "Pematahan Dormansi Bawang Merah ( Allium Ascalonicum ) Dengan Perlakuan Suhu Rendah Dan Zat Pengatur Tumbuh," Prosiding Konsep Karya Ilmiah Nasional 2019, pp. 156-162.

[14] D. R. Puspitasari, A. Nuraini, and S. Sumadi, "Pematahan Dormansi Umbi Bawang Putih (Allium sativum L.) Varietas Lumbu Hijau dengan Perlakuan Lama Penyimpanan Umbi pada Suhu Rendah dan Aplikasi Giberelin," Paspalum J. Ilm. Pertan., vol. 8, no. 2, 2020, doi: 10.35138/paspalum.v8i2.189.

[15] S. Lynikiene, A. Pozeliene, and G. Rutkauskas, "Influence of corona discharge field on seed viability and dynamics of germination," Int . Agrophysics, vol. 20, no. 3, 2006.

[16] J. B. Reece et al., "Campbell Biology (Ninth Edition)," in Biology, 2010.

[17] C. Wolverton, J. L. Mullen, H. Ishikawa, and M. L. Evans, "Two distinct regions of response drive differential growth in Vigna root electrotropism," Plant, Cell Environ., vol. 23, no. 11, 2000, doi: 10.1046/j.1365-3040.2000.00629.x.

[18] D. Dannehl, S. Huyskens-Keil, D. Wendorf, C. Ulrichs, and U. Schmidt, "Influence of intermittentdirect-electric-current (IDC) on phytochemical compounds in garden cress during growth," Food Chem., vol. 131, no. 1, 2012, doi: 10.1016/j.foodchem.2011.08.069. 
Gede Arya Wiguna, dkk : Pengaruh Medan Listrik sebagai Stimulan Pertumbuhan Bawang Putih Lokal Timor 